УДК: $316.34: 316.4$

DOI:

\author{
Кочубейник Ольга Миколаївна, \\ доктор психологічних наук, \\ провідний науковий співробітник \\ лабораторії психології політико-правових відносин, \\ Інститут соціальної та політичної психології НАПН України, \\ м. Київ, Україна \\ ORCID ID 0000-0001-6460-8494 \\ kochubeynyk@gmail.com
}

\title{
АТОМІЗАЦІЯ СУСПІЛЬСТВА, НОВІ ФОРМИ ДИСКРИМІНАЦЇ̈ ТА ДОВІРА В УМОВАХ ПАНДЕМІЇ
}

\begin{abstract}
Статтю присвячено аналізу особливостей процесу виробництва нових форм дискримінації в період пандемії та його наслідків для порядку соціальності. Показано, що пандемія знаходить вияв у докорінній трансформації повсякденності та в неможливості застосувати усталені й напрацьовані раніше надійні практики для розв'язання соціальних проблем. Це спричинює перерозподіл наявних ресурсів будь-якого порядку, що провокує виникнення нових форм дискримінації та соціальної нерівності. У просторі соціальної взаємодії внаслідок цього спостерігається конкуренція спільнот за ресурси, що означає прийняття рішення про «порядок надання допомоги» спільнотам (особам), тобто фактично йдеться про процес виробництва нерівності та нових форм дискримінації. Зазначається, що пандемія призвела до істотних «мутацій» у системі соціальних ієрархій, механізмом яких стало «накладання» тих чи тих форм дискримінації одна на одну (оскільки вони не діють ізольовано), що й спричинило формування динамічної сили як «нового гравця» в системі поляризацій українського соціуму. Робиться висновок, що пандемія істотною мірою «зміксувала» суспільство, змінивши для багатьох осіб не лише рівень доходів, а й споживчу поведінку, мотивацію, соціальні цінності тощо. Зауважується, що попередньо усталені групи починають розпадатися, віддаляються одна від одної, втрачають функціональні взаємозв'язки, проте виникнення нових спільнот не $\epsilon$ процесом настільки ж швидким. Міксування виявляється в реконструюванні відмінностей (збільшенні неоднорідності, поляризації) за політичними, ідеологічними, світоглядними, ціннісними, регіональними, мовними, культурними, етнічними ознаками, і це гальмує використання людського та соціального капіталу, знижує рівень соціальної згуртованості та суспільної довіри, посилює соціальну напруженість і нестабільність.
\end{abstract}

Ключові слова: довіра; солідарність; атомізація; ієрархія; соціальні інтеракції.

\section{ATOMIZATION OF SOCIETY, NEW DISCRIMINATIONS AND TRUST UNDER PANDEMIC SITUATION}

\author{
Olha M. Kochubeynyk, \\ Doctor of Sciences in Psychology, \\ Leading Researcher of the Laboratory of Psychology of Political and Law Relationships \\ Institute for Social and Political Psychology, NAES of Ukraine, \\ Kyiv, Ukraine \\ ORCID iD 0000-0001-6460-8494 \\ kochubeynyk@gmail.com
}

The article is dedicated to the analysis of new discrimination forms production under a pandemic situation and its consequences for the social order and solidarity. It is shown that the 
pandemic causes the global transformation of everyday life, and the personal inability to apply wellestablished, reliable practices for social problems' solving. It causes a redistribution of available resources on different levels, which provokes new forms of discrimination and the development of new forms of social inequality. In the space of social interaction, it turns into competition for resources between communities, such as decision-making on the «sequence for assistance providing» to communities (individuals), that is, in fact, is a process of producing inequality and new forms of discrimination. It is noted that the pandemic caused significant «mutations» in the system of social hierarchies. The mechanism of these mutations is the different types of discrimination «imposition» (because they are not isolated), that leads to the formation of a dynamic force that became a «new player» in the polarization of Ukrainian society. It is concluded that pandemic has significantly «mixed» the society, changing not only the income level for many people, but also changing their consumer behavior, motivation, social values, and so on. It is noted that pre-established groups begin to disintegrate, move away from each other, lose their functional relationships, but the emergence of new communities is not such a quick process. Such mixing has resulted in the reconstruction of differences (increasing heterogeneity, polarization) in political, ideological, ideological, value, regional, linguistic, cultural, ethnic characteristics, and it inhibits the use of human and social capital, reduces social cohesion and social trust, increases social tension and instability.

Keywords: trust; solidarity; atomization; hierarchy; social interactions.

Постановка проблеми. Сьогодні з упевненістю можна стверджувати, що вплив пандемії на суспільство є багатовимірною дією, а його «залежною змінною» стають усі складники порядку соціальності будь-якого його рівня. Режимно-обмежувальні заходи різного гатунку спричинили наскрізний процес змін в усіх суспільних сферах. Очевидно, що матеріальне становище значної частини людей істотною мірою погіршилося, оскільки ці заходи супроводжувалися закриттям низки підприємств, збільшенням числа безробітних (зокрема і через втрату роботи трудовими мігрантами), скороченням доходів значної частини підприємців і найманих працівників. Також повсякденність порушилася втратою «живого» спілкування, позначилася браком звичних видів соціальної активності, серед яких прогулянки містом, зустрічі в кав'ярнях, цікаве дозвілля та розваги, шопінг, робота в колективі, користування послугами (перукарні, салони краси, фітнес-центри), відвідування театральних вистав чи концертів тощо. Отож у численних публікаціях - як фахових, так $\mathrm{i}$ непрофесійних - обговорюється, наскільки введення режимів локдауну, соціального дистанціювання чи самоізоляції загрожує психологічному здоров'ю людей, ослаблює групові зв'язки, порушує соціальний та психологічний комфорт. Спільним знаменником усіх цих різнорівневих публікацій $\epsilon$ те, що пандемія як специфічний спосіб порушення повсякденності провокує докорінні соціальні зміни. На наш погляд, ці зміни матимуть істотні наслідки для функціонування порядку соціальності, а саме: пандемія як перерозподіл ресурсів будь-якого типу призведе до конструювання в суспільстві нових форм нерівностей та дискримінації.

Аналіз останніх досліджень і публікацій, виокремлення нерозв'язаних частин загальної проблеми. Проблема соціальної дискримінації (стратифікації та нерівності) отримувала різноманітні ракурси висвітлення: зокрема як наслідок класової структури або розшарування за економічними ознаками, за освітнім рівнем, за расовою та етнічною належністю тощо. Конструювання та відтворення соціальної нерівності як найважливішої артикуляти порядку соціальності розглядається в працях К. Маркса, Е. Дюркгайма, М. Вебера, П. Сорокіна, Р. Дарендорфа, Дж. Міда, Т. Парсонса, Р. Мертона, П. Штомпки, А. Шюца. Аналіз «нових нерівностей» - таких, що виникли наприкінці XX сторіччя й виникають нині внаслідок дії глобалізаційних чинників у соціальних структурах суспільств, - представлено в доробку Д. Белла, П. Бергера, Ж. Бодріяра, Н. Лумана, З. Баумана, I. Валерстайна, Е. Гіденса, М. Кастельса, Дж. Рітцера, Е. Тоффлера, Н. Смелзера, Г. Терборна, С. Гантінгтона.

Пандемія спровокувала новий вимір цих досліджень. Так, проблему стигматизації осіб iз COVID-19 на тлі поширення пандемії коронавірусу аналізує Л. Коробка (2020). У центрі 
уваги дослідників ризики, які виникають для психологічного благополуччя; соціальнопсихологічні ефекти пандемії, що потенціюють порушення психічного здоров'я; ефекти впливу засобів масової інформації та соціальних мереж на психічний стан людей (Юрьева, \& Шустерман, 2020).

Мета статті полягає в аналізі особливостей процесу виробництва нових форм дискримінації в період пандемії та його наслідків для порядку соціальності.

Виклад основного матеріалу дослідження. Пандемія істотно порушила повсякденність як напрацьований, налагоджений спосіб задоволення потреб, в основі якого використання соціальної структури суспільства, його «людського» устрою. Зрозуміло, що міра задоволення цих потреб - як узвичаєної фіксації символічного статусу особи чи спільноти - різнилася, проте саме вона визначала динаміку суспільних інтеракцій. Адже структура будь-якого суспільства - це насамперед система неоднорідностей, спричинена функціональною диференціацією суспільства. I будь-яке суспільство мусить зберігати систему неоднорідностей як упорядковане начало, без якого не зможе відтворювати соціальні зв'язки, забезпечувати ефективне функціонування інститутів, здійснювати контроль за діяльністю багатьох сегментів, яким притаманна різна міра автономності. Іншими словами - забезпечувати відтворення порядку соціальності («хтось має пекти хліб, хтось - воювати»).

Порядок соціальності ми визначаємо як сукупність процедур систематичного виробництва відносин владності/підвладності та їхніх символізацій у конкретному соціокультурному середовищі, що об'єктивно проявляється в реальних дотримуваних практиках соціальних взаємодій, а суб'єктивно переживається як прийнятність норм, цілей та ідеалів, відтворюваних цими практиками. I в цьому сенсі будь-який порядок соціальності, отже, є формою контролю системи нерівностей, встановлюючи іiі (і підтримуючи іiі) через зміст таких символічних конструкцій, як сексуальна ідентичність, раса, етнічна належність, релігія, громадянство, вік, соціально-економічний статус, фізичні і розумові здібності тощо. Ідеться про те, що нерівність виникає тоді, коли неоднорідність починає символізуватися, тобто виникає ієрархія статусів, що закріплюють певні владні можливості, блага та ресурси задоволення потреб. Але тут слід увиразнити основну закономірність у конструюванні нерівностей та дискримінацій: будь-яка якість, властивість, ресурс можуть стати підставою для виникнення дискримінаційних та ієрархічних відносин і що більш обмеженим є цей ресурс у суспільстві, то більше проявів нерівності в процесі його розподіляння можемо спостерігати.

3 часом одні нерівності дезактуалізуються, переходять у латентний стан і можуть бути значущими лише в парціальних порядках соціальності. Другі - навпаки, з'являються на соціальній арені й потужно починають диференціювати суспільство. (У такому сенсі ми зараз говоримо про цифрову нерівність). Треті - змінюють свій «знак». (Наприклад, фертильність у патріархальних суспільствах була основою для поваги й вищого соціального статусу на противагу неспроможності народжувати. Це навіть могло бути причиною розірвання церковного шлюбу. Сьогодні ж багатодітність $є$ радше підставою для стигматизації, оскільки переважно вона поєднується 3 низьким економічним статусом та відповідними поведінковими практиками).

Зміна характеру нерівностей у розподілі обов'язків і зобов'язань, прав і привілеїв у межах одного виміру рано чи пізно спричинить зміну порядку соціальності загалом. Намагання різних соціальних рухів скасувати владні ієрархії, що зумовлюють несправедливий розподіл ресурсів і структурне пригнічення в політиці соціальних інститутів та в повсякденному житті, призводять - поки що - лише до заміни однієї системи привілеїв на іншу. В окремих рефлексіях цей феномен дістав назву «терору меншин». Ось, наприклад, яскрава ілюстрація. Усі звикли до феміністичних рухів різного забарвлення, але виявився несподіванкою заклик не святкувати 250-річчя Л. ван Бетховена, оскільки він «надто білий, надто маскулінний і надто затхлий» (too male, too pale, too stale). Його симфонію №5, яка 3 1808 року була метафорою сили духу композитора, було переозначено: іiі символізація 
дістала іншу інтерпретацію. Зазначалося, що попередня оцінка була віддзеркаленням ставлення «людей при владі», тобто білих заможних чоловіків, які «прийняли» Л. ван Бетховена і зробили із симфонії символ своєї вищості і значущості. Проте для деяких груп - жінок, представників ЛГБТ та расових меншин - ця симфонія є дошкульним нагадуванням про історію дискримінації та елітизм класичної музики.

Але повернімося до предмета дослідження. Пандемія як соціальна конструкція знаходить вияв у неможливості застосувати усталені й напрацьовані раніше надійні практики розв'язання соціальних проблем тих чи тих спільнот або окремих осіб. Останнє спричинює перерозподіл наявних ресурсів будь-якого порядку, що, зрозуміло, провокує виникнення нових форм дискримінації та соціальної нерівності. У просторі соціальної взаємодії внаслідок цього спостерігається конкуренція спільнот за ресурси, що, зрештою, означає прийняття рішення про «порядок надання допомоги» спільнотам (особам), тобто фактично йдеться про процес виробництва нерівності та нових форм дискримінації. Інакше кажучи, пандемія є ситуацією, у якій відбувається «перезапуск» системи соціальних ієрархій, нерівностей та дискримінацій.

Варто пам'ятати, що будь-яка нерівність тягне за собою ряд комплексних проблем. По-перше, нерівності, що фіксують брак вибору і можливостей у частини суспільства (наприклад, обмеженість доступу до освіти або медичного захисту), породжують соціальну напруженість і політичну нестабільність. По-друге, ці нерівності звужують персональний потенціал участі особи в житті суспільства, редукують іiі представницькі функції (іноді - аж до соціальної ексклюзії), що становить серйозний виклик основним тенденціям розвитку світового порядку. Мало того, механізми виробництва нерівностей (вікової, економічної, етнічної, гендерної тощо) діють не ізольовано, а взаємно зумовлюють один одного, відтворюючи комплексну матрицю владно-ієрархічних відносин і позицій.

На нашу думку, пандемія 3 точки зору порядку соціальності призвела до істотних «мутацій» саме в цій системі ієрархій. Механізмом цих мутацій стало «накладання» тих чи тих форм дискримінації одна на одну (оскільки вони не діють ізольовано), що й спричинило в кінцевому підсумку формування динамічної сили як «нового гравця» в системі поляризацій українського соціуму.

Але спочатку проаналізуймо, які нерівності найбільшою мірою актуалізувалися в період пандемії. Чільне місце, безперечно, посідає економічна нерівність, яка, можливо, має бути винесена за дужки цього аналізу: за будь-якого порядку соціальності (крім утопічного) вона є визначальним регулятором конструювання уявлень про справедливість, рівність прав та рівність можливостей. Найбільш наочно вона оприявнюється в різниці у доступі до основних соціальних благ (якісного медичного обслуговування, якісної освіти, комфортного житла) та реалізації основних прав (права на здоров'я, життя, безпеку тощо).

Наразі тією нерівністю, яка найбільшою мірою увиразнилася в системі владноієрархічних відносин і позицій, $\epsilon$, мабуть, нерівність доступу до отримання медичної допомоги. Зазначимо, що йдеться навіть не про «якісну» допомогу, а взагалі - можливість госпіталізації, наявність апаратів штучної вентиляції легень, кисневих концентраторів, ліків тощо. (Між «Феофанією» і районною лікарнею різниця зрозуміла без коментарів). Інший прояв, який є болючим для українців, - це нерівність у доступі до вакцин. У масових дискурсах усталилася позиція, що олігархи та депутати вакцинуватимуться контрабандним «Файзером», а пересічних громадян максимум що очікує - це «священні води Гангу», як охрестили CoviShield.

Продовжити перелік слід згадкою про регіональну нерівність, адже відмінності в організації повсякденності, що існують для мешканців різних за величиною населених пунктів, виявляються також у доступі до послуг соціальної сфери. (Так, наприклад, у селах уже багато років триває процес масового «вибуття» 3 експлуатації медичних, освітніх та культурно-побутових об’єктів, тоді як у населених пунктах районного та обласного значення цей дефіцит менш помітний). Проте пандемійний формат регіональної нерівності знайшов вияв у формах дотримання режимно-обмежувальних закладів. Приміром, призупинення руху 
громадського транспорту у великих містах блокувало не лише пересування, а й вирішення багатьох значущих (зокрема і виробничих) питань, тоді як для маленьких міст це було не так помітно. Дотримання режиму використання засобів індивідуального захисту в селах зазвичай менш жорстке, ніж у містах. I, нарешті, карантинне зонування - червона, помаранчева, жовта, зелена зони - $є$ чіткою і прозорою символізацією міри дозволеного і забороненого.

Істотних змін зазнав простір професійних нерівностей. Пандемія викликала не тільки безробіття (втрату робочого місця загалом або неповну зайнятість), не лише негативно вплинула на оплату праці, а й створила додатковий вимір нерівності: можливість/ неможливість дистанційної роботи. Зокрема, ті сфери, що пов'язані з безпосереднім, «очним» контактом із клієнтом, створювали вищі ризики захворюваності і, відповідно, розцінювалися як менш привабливі. А «бюджетники», якщо це не медичні і не педагогічні працівники, виявилися в привілейованому становищі, оскільки цій сфері приписувався дистанційний формат роботи та збереження заробітної плати.

Вікова нерівність проявилася, на наш погляд, на обох полюсах позиції. Зрозуміло, що найбільш вразливою категорією для впливу пандемії стали люди старшого віку (65+), адже для них нерівність постала як неможливість зустрічатися 3 дітьми та онуками, як обмежувальні заходи щодо пересування (що ускладнювало купівлю ліків та продуктів), як згубний вплив агресивного інформаційного середовища. В окремих випадках - ризик звільнення. Крім того, загроза задіяння протоколів медичного сортування маркувала цю вікову групу як «меншовартісну». Для молоді нерівність проявилася як обмеження спілкування, проблематична самоізоляція в гуртожитках, різка зміна формату навчання i часто - втрата його якості, скорочення доступних вакансій на ринку зайнятості тощо.

Статева нерівність також зазнала специфічних пандемійних форматувань: основні порушення на робочому місці (позапланова відпустка «за свій рахунок», збільшення навантаження, скорочення розмірів заробітної плати за виконання того ж обсягу роботи) виявлялися частіше проблемою жінок, аніж чоловіків. Крім того, проблема дитячих садочків, які призупинили своє функціонування, або проблема шкільних уроків (зокрема, контролю за перебігом дистанційних занять) також виявилися переважно «жіночими» проблемами.

Нерівність у системі символічного капіталу, де диференціація виникає через відмінності в доступі до соціально значущої інформації, можливості іiі інтерпретації, здатності нав'язувати певне ії тлумачення іншим, також долучилася до поділу суспільства. Адже протягом тривалого часу поширювалася суперечлива інформація про пандемію, включаючи чутки, плітки та інші неперевірені відомості, проте можливість формування адекватного образу реальності виявилася різною. Інфодемія для більшості виявилася критичною атакою на свідомість, інші (іх менше) не поспішали користуватися «порадами лікаря Юри з Уханя».

Але повернімося до вихідної тези про виробництво нерівностей - нерівності не діють ізольовано, а накладаються одна на одну. Так, «вік 65+», крім того що маркується як вразливий (тобто меншовартісний), означає також цифрову нерівність, тобто проблеми 3 доступом до безпечного придбання товарів та ліків за допомогою інтернет-сервісів, оскільки літні люди переважно не мають таких навичок, а регіональна нерівність може зростати через відсутність медичного закладу, який міг би надати кваліфіковану допомогу.

Іншими словами, порушення практик повсякденності постає більш масштабним, ніж це може здаватися на перший погляд, а чільними його чинниками є не обмеження контактів та скорочення доходів. Пандемія змінює наявні порядки соціальності тим, що через комплексну зміну системи нерівностей вона створює підстави для нової поляризації. I, 3 точки зору загальної соціальної динаміки, Україна, яка постійно намагається долати територіальні, мовні, релігійні, внутрішньо- і зовнішньополітичні поляризації, дістала ще одну - морально-гуманістичну. На нашу думку, пандемія сформувала соціальний розлом, який стає потужним інструментом поглиблення соціальної неоднорідності: постала необхідність робити вибір «між економікою і життям», тобто вибір між економічним прибутком і цінністю людського життя. Власне, виник розлом між тими, хто боїться 
«померти від голоду», і тими, хто боїться «померти від вірусу», що позначається на змісті вимог, декларацій, очікувань i на формуванні різних моделей майбутнього. Фактично виникла нова поляризація, яка істотною мірою долучилася до системи виробництва ієрархій та дискримінацій. Звичні, ну, скажімо, великі поляризації - такі, як ліві/праві, європрихильники/євроскептики, чоловіки/жінки, - поступилися місцем «тимчасовим», таким, що враховують ось цей актуальний поділ.

Важливо підкреслити, що зміна в системі ієрархій та дискримінацій означає не тільки зміну порядку соціальності, а й зміну основ ідентифікації, зміну функціонування системи ідентичностей. «Мутації» в системі привілеїв та дискримінацій призвели до збільшення соціальної неоднорідності, зростання напруженості між різними ідентичностями та, відповідно, розбалансування системи солідарності й інтенсифікації процесів соціальної атомізації.

Атомізація суспільства, з одного боку, є його органічним процесом, який час від часу то посилюється, то послаблюється, тому критичним є не сам факт його наявності та його зміст (зниження ролі колективних цінностей, ерозія солідарності, масові прояви соціальної роз'єднаності, зниження потенціалу колективізму), а інтенсивність наростання. 3 другого боку - у своїй найвищій фазі він $є$ загрозою для чинного порядку соціальності, а його провокацією є множення й накладання одна на одну різноманітних причин. Так, Україна у процес вибудовування власного порядку соціальності («історична причина») увійшла вже у стані високої атомізації, адже вона мала спадок у вигляді періоду перебудови, коли на всьому пострадянському просторі виникали нові ринкові економічні відносини, руйнувалися зв'язки між суб'єктами господарювання. Тобто атомізація стала закономірним наслідком стрімкого переходу від радянської системи до «ринкової моделі», що супроводжувався прийняттям абсолютною більшістю населення нових настановлень, пов'язаних 3 пріоритетним значенням конкуренції, ідей особистого збагачення та індивідуального процвітання, форми досягнення яких часто виявлялися поза правовим полем або ж поза уявленнями про порядність, прийнятність, чесність. На «історію» накладається поширення неоліберальних ідей, які наголошують на особистій відповідальності за своє власне життя, спрямовані на персональне економічне процвітання, підвищення рівня індивідуального матеріального добробуту, тобто пропонують атомарність. Слід також назвати й психологічну причину експлозивного наростання ступеня соціальної атомізації, а саме: наявність гострих відмінностей у поглядах на соціальні реалії (що регулярно засвідчує Центр Разумкова (Разумков Центр, 2020), призводить до «інкапсуляції», тобто, щоб уникнути гострих конфліктів, пов'язаних 3 протилежністю позицій, люди намагаються мінімізувати інформацію, яка «виходить назовні», про свої уподобання та міркування, замикаючись у своєму «інформаційному коконі». Останнє порушує дієвість актуальної регулятивної системи ідентичностей, адже іiі фундаментальним законом є об'єднання «своїх» проти «чужих» заради збереження й відтворення «свого» способу тлумачення картини світу (необхідного, бажаного, припустимого тощо).

Звісно, атомізація суспільства $є$ комплексним ефектом, але наразі нас більше цікавлять ii наслідки, а не детальний перелік чинників іiі виникнення. I, на нашу думку, найбільш небезпечним соціально-психологічним наслідком є втрата спільної валентної соціальної тканини. Соціальне роз'єднання, послаблення зв'язків між людьми призводять, 3 одного боку, до зростання відхилень від загальноприйнятих норм: аномія та нехтування приписами моралі межують з тотальним індивідуалізмом. 3 другого боку - атомізація позначається на ступені залученості особи в політичну та громадську діяльність, істотною мірою його знижуючи, та проявляється як брак уявлень про проблеми спільного характеру, що могли б розв'язуватися колективними зусиллями.

Висновки та перспективи подальших досліджень. Зазначимо, що зміна системи ієрархії та дискримінації - об’єктивно чи суб'єктивно зумовлена, короткочасна чи довгострокова, транзиторна чи необернена - збільшує ступінь неоднорідності суспільства та в кінцевому підсумку зачіпає його економічні, політичні, духовні основи, що неодноразово в 
історії призводило до «вибухових» за своїм характером змін порядку соціальності.

Пандемія, на нашу думку, істотною мірою «зміксувала» суспільство, змінивши не лише рівень доходів, а й споживчу поведінку, мотивацію, соціальні цінності тощо багатьох осіб. Атомізація виявляється, як було показано, у тому, що попередньо усталені групи починають розпадатися, віддалятися одна від одної, втрачати функціональні взаємозв'язки, а виникнення нових спільнот не $є$ процесом настільки ж швидким. I в ситуації, що склалася, виникає проблема підтримання ефективного функціонування соціальної системи, відтворення порядку соціальності, який давав би змогу задовольняти вимогу більш-менш коректної співдії всіх систем, оскільки, якщо немає взаємодії між групами, немає соціальної солідарності, що грунтується на довірі до суспільних інститутів та окремих осіб, виникає ризик встановлення авторитарного режиму. Інакше кажучи, що більш неоднорідним $\epsilon$ суспільство, що більш напружені відносини між спільнотами, провоковані дискримінаціями та ієрархіями (а це, власне, два основних аспекти атомізації), то вищим є ризик появи на політичній арені «силової меншості».

Проблема нерівності тісно пов'язана 3 проблемою соціальної згуртованості, соціального залучення, суспільної довіри. Це означає, що соціальну політику слід орієнтувати на згуртування суспільства. Пандемія супроводжується масштабними змінами у всіх сферах діяльності суспільства, зокрема приводить до трансформації критеріїв соціальної нерівності та появи нових форм дискримінації. У певному сенсі ця ситуація - це перезапуск дискурсів, що конструюють порядок соціальності. А тому нова динаміка суспільних процесів, що виникає, вимагає вивчення різних характеристик нерівності, особливо з огляду на те, що соціальна ідентифікація індивідів у цей період гостро й постійно змінюється. Вони по-різному відчувають нерівність і своє становище в соціальній структурі суспільства. Ескалація нерівності, отже, є реальною основою для соціальної напруженості, оскільки становить загрозу для безпеки і особистості, і суспільства, а тому потребує детального вивчення.

\section{Список використаних джерел}

Коробка, Л. М. (2020). Стигматизація осіб із COVID-19 в умовах поширення пандемії коронавірусу: соціально-психологічний аспект. Проблеми політичної психологіi, 23(1), 94-109.

Разумков Центр (2020). Оиінка громадянами ситуаџії в країні, рівень довіри до соиіальних інститутів та політиків, електоральні орієнтаиії громадян (жовтень-листопад 2020 р.). Взято 3 https://razumkov.org.ua/napriamky/sotsiologichni-doslidzhennia/otsinka-gromadianamy-sytuatsii-v-krainiriven-doviry-do-sotsialnykh-instytutiv-ta-politykiv-elektoralni-oriientatsii-gromadian-zhovten-lystopad2020r. (12.05.2021)

Юрьева, Л. Н., \& Шустерман, Т. И. (2020). Пандемия COVID-19: риски для психологического благополучия и психического здоровья. Украӥнський вісник психоневрологіï, 28(2), 5-10.

\section{References}

Korobka, L. M. (2020). Styhmatyzatsiia osib iz COVID-19 v umovakh poshyrennia pandemii koronavirusu: sotsialno-psykholohichnyi aspekt [Stigmatization of people with COVID-19 in the context of the spread of the coronavirus pandemic: a socio-psychological aspect]. Problemy politychnoi psykholohii, 23 (1), 94-109. (in Ukrainian)

Razumkov Tsentr (2020). Otsinka hromadianamy sytuatsii $v$ kraini, riven doviry do sotsialnykh instytutiv ta politykiv, elektoralni oriientatsii hromadian (zhovten-lystopad $2020 \mathrm{r}$.) [Citizens' assessment of the situation in the country, the level of trust in social institutions and politicians, electoral orientations of citizens (October-November 2020)]. Retrieved from https://razumkov.org.ua/napriamky/sotsiologichnidoslidzhennia/otsinka-gromadianamy-sytuatsii-v-kraini-riven-doviry-do-sotsialnykh-instytutiv-ta-politykivelektoralni-oriientatsii-gromadian-zhovten-lystopad-2020r. (12.05.2021). (in Ukrainian)

Yuryeva, L. N., \& Shusterman, T. Y. (2020). Pandemiya COVID-19: riski dlya psikhologicheskogo blagopoluchiya i psikhicheskogo zdorovya. Ukrainskyi visnyk psykhonevrolohii [Ukrainian Bulletin of Psychoneurology], 28 (2), 5-10. (in Russian) 